\title{
MIMOSMLUVNÍ ZÁVAZKOVÉ POMĚRY S MEZINÁRODNÍM PRVKEM Z POHLEDU ČESKÉ AUTONOMNÍ ÚPRAVY
}

\author{
KATEŘINA HOLEČKOVÁ
}

\begin{abstract}
Non-contractual Obligations with Cross-border Elements in the Context of Czech Private International Law

Private International Law is nowadays, to a large extent, regulated by European and international law and the scope of the application of autonomous national law is therefore limited. However, in case of non-contractual obligations with cross-border elements, this scope is still relatively broad, as certain matters are excluded from the regulation on the European and international level. The aim of this article is to analyze the regulation of non-contractual obligations with cross-border elements under the Czech Act on Private International law, namely its regulation of international jurisdiction, applicable law, and the recognition and enforcement of foreign judgements.
\end{abstract}

Keywords: non-contractual obligations; Act on Private International Law; international jurisdiction; applicable law

Klíčová slova: mimosmluvní závazky; zákon o mezinárodním právu soukromém; mezinárodní pravomoc; rozhodné právo

DOI: $10.14712 / 23366478.2021 .27$

\section{1. ÚVODEM}

Při řešení přeshraničních mimosmluvních závazkových poměrů je stejně jako u každého jiného soukromoprávního poměru s mezinárodním prvkem nezbytné najít odpověd' na tři základní otázky mezinárodního práva soukromého. Zaprvé, u soudu jakého státu jsem oprávněn podat žalobu (otázka mezinárodní soudní př́islušnosti, resp. pravomoci), zadruhé, podle jakého práva bude daný právní poměr posuzován (otázka rozhodného práva), a zatřetí, jak bude s rozhodnutím nakládáno v zahraničí (otázka uznání a výkonu cizích rozhodnutí).

V českém právním řádu nalezneme odpovědi na tyto otázky v zákoně č. 91/2012 Sb., o mezinárodním právu soukromém (dále jen „ZMPS“), kdy předmětem jeho úpravy jsou vedle kolizních norem i normy mezinárodního práva procesního a normy soukromého cizineckého práva.

ZMPS ovšem není $\mathrm{v}$ tomto ohledu jediným pramenem práva - jak je uvedeno $\mathrm{v}$ jeho $\S 2$, použije se této zákonné úpravy pouze ,,v mezích ustanoveni vyhlášených meziná- 
rodních smluv, kterými je Česká republika vázána, a př́mo použitelných ustanovení práva Evropské unie ". ${ }^{1}$ Konkrétně úpravu mimosmluvních závazkových poměrů s mezinárodním prvkem nalezneme jak v unijním právu, tak v mezinárodních smlouvách.

Otázka mezinárodní př́ślušnosti je tak na unijní úrovni upravena v Nařízení Brusel I bis o př́slušnosti a uznávání a výkonu soudních rozhodnutí v občanských a obchodních věcech (dále jen „Nařízení Brusel I bis“), ${ }^{2}$ které je přímo aplikovatelné a na základě kterého je mezinárodní př́slušnost určována vždy, když má žalovaný bydliště $\mathrm{v}$ členském státě EU, ${ }^{3} \mathrm{a}$ v určitých př́ípadech i bez splnění této podmínky. ${ }^{4}$ Luganská úmluva z roku 2007 uzavřená mezi EU, Dánskem, Islandem, Norskem a Švýcarskem ${ }^{5}$ obsahuje obdobnou úpravu pro otázky mezinárodního procesního práva, kdy pro vztahy mezi těmito státy přejímá pravidla Nařízení Brusel I, ${ }^{6}$ právního předchůdce Nařízení Brusel I bis. Podle Haagské úmluvy o dohodách o volbě soudu ${ }^{7}$ je mezinárodně příslušný k projednání soud smluvního státu úmluvy, který si strany v souladu s úmluvou zvolily za mezinárodně př́ślušný. ${ }^{8}$ Relevantním pramenem jsou i bilaterální smlouvy o právní pomoci. ${ }^{9}$

Výše uvedenými prameny je často zároveň upravena i otázka uznání a výkonu cizích rozhodnutí. V Nařízení Brusel I bis, v Luganské úmluvě a bilaterálních smlouvách jsou stanovena pravidla pro uznání a výkon rozhodnutí vydaných soudy či jinými orgány členských či smluvních států, podle pravidel Haagské úmluvy o dohodách

1 Toto ustanovení je nicméně čistě deklaratorního charakteru, nebot přednostní užití těchto pramenů by i bez výslovné úpravy v zákoně vyplývalo př́mo z ústavního pořádku ČR a práva EU. Viz BŘíZA, P. Nový český zákon o mezinárodním právu soukromém v kontextu práva EU a mezinárodních smluv. Právní rozhledy. 2013, č. 17 , s. 580.

2 Nařízení Evropského parlamentu a Rady (EU) č. 1215/2012 ze dne 12. 12. 2012 o př́slušnosti a uznávání a výkonu soudních rozhodnutí v občanských a obchodních věcech.

3 Viz čl. 5 odst. 1 Nařízení Brusel I bis. Mezi členské státy EU se ovšem v tomto ohledu nepočítá Dánsko, které se přijímání nařízení díky svému specifickému postavení nezúčastnilo - viz Odrážka (41) Preambule k Nařízení Brusel I bis. Mezi EU a Dánském však byla uzavřena dohoda o př́slušnosti a uznávání a výkonu soudních rozhodnutí v občanských a obchodních věcech, jejímž účelem je zajistit uplatňování ustanovení Nařízení Brusel I (bis) v Dánsku. Viz čl. 1 dohody a Úřední věstník EU L 79/4 ze dne 21. 3. 2013.

4 V souladu s čl. 6 odst. 1 Nařízení Brusel I bis se jedná o př́islušnost založenou na ustanovení o výlučné př́slušnosti (čl. 24), dohodnuté př́slušnosti (čl. 25), spotřebitelských sporech, pokud jsou vedeny ze strany spotřebitele (čl. 18 odst. 1), a sporech se zaměstnavatelem vedených zaměstnancem (čl. 21 odst. 2).

5 Úmluva o př́slušnosti a uznávání a výkonu soudních rozhodnutí v občanských a obchodních věcech, podepsaná smluvními stranami v Luganu dne 30. 10. 2007, schválená rozhodnutím Rady ES ze dne 27. 11. 2008, č. 2009/430/ES.

6 Nařízení Rady (ES) č. 44/2001 ze dne 22. 12. 2000 o př́slušnosti a uznávání a výkonu soudních rozhodnutí v občanských a obchodních věcech.

7 Haagská úmluva o dohodách o volbě soudu je pro ČR závazná, nebot' ji v roce 2009 podepsala a v roce 2015 schválila EU. Viz rozhodnutí Rady 2014/887/EU ze dne 4. 12. 2014 o schválení Haagské úmluvy ze dne 30. 6. 2005 o dohodách o volbě soudu jménem EU. V platnost úmluva vstoupila dne 1. 12. 2015.

8 Viz čl. 5 Haagské úmluvy o dohodách o volbě soudu.

9 Většina těchto smluv byla uzavřena tehdejší Československou socialistickou republikou s dalšími státy bývalého východního bloku, přičemž pro ČR jako jeden z nástupnických států Československa jsou tyto smlouvy i nadále závazné. Viz čl. 5 odst. 2 ústavního zákona č. 4/1993 Sb., České národní rady o opatřeních souvisejících se zánikem České a Slovenské Federativní Republiky. Přehled těchto smluv lze najít na stránkách Ministerstva spravedlnosti (viz Dvoustranné smlouvy: přehled hlavních dvoustranných smluv o mezinárodní právní pomoci v oblasti trestní a civilní a dokumentů souvisejících. In: justice.cz: katalog životních situací [online]. [cit. 2021-03-23]. Dostupné na: https://justice.cz/web/msp/dvoustranne -smlouvy). 
o volbě soudu bude uznán a vykonán v jiném smluvním státě rozsudek takového soudu smluvního státu, který byl jako př́slušný v souladu s úmluvou určen v prorogační dohodě. ${ }^{10}$

Na unijní úrovni jsou unifikovány i kolizní normy, konkrétně v Nařízení Řím II o právu rozhodném pro mimosmluvní závazkové vztahy. ${ }^{11}$ Opět se jedná o př́mo aplikovatelné nařízení, které budou soudy členských států aplikovat vždy, pokud daný mimosmluvní závazkový vztah s mezinárodním prvkem bude spadat do jeho věcné působnosti. Z mezinárodních smluv je kolizní úprava obsažena v Haagské úmluvě o právu použitelném pro dopravní nehody, která pro Českou republiku (resp. Československou socialistickou republiku) vstoupila v platnost dne 11. 7. 1976. ${ }^{12}$ Kolizní úpravu nalezneme i v některých bilaterálních smlouvách o právní pomoci.

Úprava obsažená v ZMPS má tak poměrně omezený rozsah - někdy také bývá označována za zbytkovou normu. ${ }^{13}$ Zároveň se ovšem v žádném př́padě nejedná o úpravu, kterou by bylo možné zcela přejít, nebot jak bude uvedeno níže, $v$ př́padě mimosmluvních závazkových poměrů zůstává prostor pro aplikaci autonomního mezinárodního práva soukromého stále poměrně významný.

Cílem tohoto článku je představit stávající českou právní úpravu mimosmluvních závazkových poměrů s mezinárodním prvkem a kriticky zhodnotit, zda je tato úprava (zejména ve srovnání s úpravou unijní) úpravou vhodnou.

\section{PRAVOMOC ČESKÝCH SOUDŮ PODLE ZMPS}

Pravomoc českých soudů k rozhodování soukromoprávních poměrů s mezinárodním prvkem je v ZMPS upravena hned na několika místech. Obecnou úpravu nalezneme $\mathrm{v}$ rámci obecné části mezinárodního práva procesního $\mathrm{v} \S 6$ an, ve zvláštní části ZMPS nalezneme pro vybrané právní poměry odchylky od obecného pravidla, které otázku pravomoci upravují zvlášt' jako lex specialis.

Pro mimosmluvní závazkové poměry nicméně ve čtvrté, zvláštní části ZMPS, konkrétně v Hlavě XI (Závazková práva), žádnou zvláštní úpravu nenalezneme. Jediné ustanovení o pravomoci je v rámci této hlavy ustanovení § 85 ZMPS, které stanoví, že pravomoc českých soudů ve věcech závazkových a jiných majetkových práv může být založena také písemnou dohodou stran. $\mathrm{V}$ př́padě, že $\mathrm{k}$ uzavření takové dohody nedojde, bude tedy pro mimosmluvní závazkové poměry relevantní úprava obsažená v obecné části mezinárodního práva procesního.

10 Viz čl. 8 a násl. Haagské úmluvy o dohodách o volbě soudu.

11 Nařízení Evropského parlamentu a Rady (ES) č. 864/2007 ze dne 11. 7. 2007 o právu rozhodném pro mimosmluvní závazkové vztahy.

12 Vyhláška č. 130/1976 Sb., ministra zahraničních věcí o Úmluvě o právu použitelném pro dopravní nehody.

13 PAUKNEROVÁ, M. Prostor pro uvážení v českém mezinárodním právu soukromém: ohlédnutí se za mezinárodním právem soukromým k výročí Antonína Hobzy. Právník. 2016, roč. 155, č. 1, s. 13. 
Obecné pravidlo pravomoci českých soudů k rozhodování o soukromoprávním poměru s mezinárodním prvkem nalezneme tedy v $\S 6$ ZMPS. Ten stanoví, že jejich pravomoc je dána $\mathrm{v}$ př́padech, kdy je podle procesních předpisů pro řízení místně př́íslušný soud na území ČR, pokud z ustanovení ZMPS nebo jiného právního předpisu nevyplývá něco jiného. Vazbou právě na místní příslušnost má být vyjádřena nutná míra intenzity vztahu k určitému území, která „opravňuje“ stát založit pro určité spory pravomoc jeho soudů $\mathrm{k}$ řešení. ${ }^{14}$

Místní př́íslušnost českých soudů je pro účely nalézacího řízení upravena v $\S \S 84-89$ a OSŘ. ${ }^{15}$ Při jejich aplikaci však nesmíme zapomenout na př́padnou aplikační přednost Nařízení Brusel I bis - $\mathrm{k}$ aplikaci $\S 84$ a násl. OSŘ prostřednictvím odkazu v $§ 6$ ZMPS dojde v podstatě pouze v situacích, kdy má žalovaný bydliště mimo EU. Irelevantním je tak založení místní příslušnosti na základě bydliště žalovaného podle $\S 85$ odst. 1 OSŘ - pravomoc českých soudů však může založit skutečnost, že se v ČR žalovaný zdržuje. ${ }^{16}$

\subsection{PŘÍSLUŠNOST DANÁ NA VÝBĚR}

V § 87 OSŘ pak nalezneme pravidla alternativní příslušnosti neboli př́islušnosti dané na výběr, která dávají žalobci možnost žalovaného žalovat i u jiných soudů než u obecného soudu žalovaného podle $\S \S 85-86$ OSŘ.

Možnost stanovená v $\$ 87$ písm. b) OSŘ je výslovně zaměřená na př́ípady žalob na náhradu újmy. Podle tohoto ustanovení je k projednání žaloby místně příslušný i soud, kde došlo ke skutečnosti, která zakládá právo na náhradu újmy. I když je zde použitý termín , ,mista, kde došlo ke skutečnosti, která zakládá právo na náhradu újmy “, na první pohled poměrně jednoznačný, ${ }^{17}$ nepanuje ohledně jeho výkladu stoprocentní shoda. Podle převažujícího výkladu obecných soudů je skutečností, která zakládá právo na náhradu újmy, pouze porušení povinnosti či jiná škodná událost (tedy příčina újmy), nikoli i její následek spočívající v projevení se újmy. ${ }^{18} \mathrm{~V}$ komentářové literatuře se ovšem setkáme i s názorem, že tento restriktivní výklad je v rozporu s jazykovým, systematickým, logickým i teleologickým výkladem pojmu „,skutečnost“ a celého

14 ROZEHNALOVÁ, N. Určení fóra a jeho význam pro spory s mezinárodním prvkem II. Bulletin advokacie. 2005, č. 5, s. 12.

15 Ustanovení o místní př́íslušnosti bychom v českém právním řádu nalezli i v zákoně č. 292/2013 Sb., o zvláštních řízeních soudních, ten nicméně obsahuje natolik specifickou úpravu tzv. nesporných řízení, že jeho ustanovení na tomto místě v kontextu výkladu § 6 ZMPS zahrnuta nebudou. V rámci ř́zení vykonávacího jsou i v mezinárodním kontextu prostřednictvím odkazu v § 6 ZMPS aplikována ustanovení o místní př́slušnosti dle $\S 45$ zákona č. 120/2001 Sb., o soudních exekutorech a exekuční činnosti (exekuční řád). Viz usnesení Nejvyššího soudu ze dne 8. 10. 2013, sp. zn. 28 Nd 228/2013.

16 BŘICHÁČEK, T. Komentář k § 6. In: BŘÍZA, P. - BŘICHÁČEK, T. a kol. Zákon o mezinárodním právu soukromém: komentár. Praha: C. H. Beck, 2014, s. 43.

17 Srov. např. formulaci čl. 7 odst. 2 Nařízení Brusel I bis, podle kterého je žalobce oprávněn žalovaného žalovat u soudů ,,místa škodné události“, a rozsudek SDEU ze dne 30. 11. 1976, Handelskwekerij Bier v. Mines de Potasse d'Alsace, C-21/76, ve kterém SDEU uvedl, že místo škodné události zahrnuje jak místo, kde škoda vznikla, tak místo, kde došlo ke škodlivému jednání (místo příčinné události).

18 Usnesení Městského soudu v Praze ze dne 28. 5. 2019, sp. zn. 22 Co 91/2019. 
ustanovení. ${ }^{19} \mathrm{~V}$ tomto ohledu je poněkud překvapivé, že tato zásadní otázka dlouho nebyla předmětem rozhodování Nejvyššího soudu - až v loňském roce bylo vydáno rozhodnutí, kterým se Nejvyšší soud přiklonil k širšímu výkladu, zahrnujícímu i místo újmy. ${ }^{20}$ Stalo se tak ovšem ve specifickém př́padě neoprávněného zásahu do osobnosti člověka, a závěry daného rozhodnutí tak podle mého názoru není možné zobecňovat.

Ustanovení § 87 OSŘ o př́slušnosti dané na výběr dávají žalobci možnost žalovat žalovaného u jiného soudu, než je jeho obecný soud - první věta tohoto ustanovení explicitně stanoví, že uvedené soudy jsou př́islušné vedle obecného soudu žalovaného. Obecně tedy platí, že podmínkou pro tuto volbu je skutečnost, že žalovaný má svůj obecný soud, tj. že má v ČR bydliště, nebo se zde zdržuje. ${ }^{21}$ Uvedené ovšem neplatí v př́ípadě aplikace těchto ustanovení prostřednictvím $\S 6$ ZMPS, který pravomoc českých soudů váže na existenci místně př́slušného soudu - tedy jakéhokoli místně prríslušného soudu. Podle judikatury je tak možné pravomoc českých soudů založit i pouze na tom, že $\mathrm{v}$ ČR došlo ke skutečnosti, která zakládá právo na náhradu škody podle $\S 87$ písm. b) OŠ̌, ${ }^{22}$ a tedy pouze na základě alternativní př́íslušnosti.

\subsection{VYNĚTÍ Z PRAVOMOCI ČESKÝCH SOUDŮ A DŮSLEDKY NEDOSTATKU PRAVOMOCI}

Pravomoc soudu ve věci rozhodnout patř́i mezi podmínky řízení, $\mathrm{k}$ jejichž splnění přihlíží soud i bez návrhu podle § 103 OSŘ v každé fázi řízení. Nedostatek pravomoci soudu danou věc projednat a rozhodnout je neodstranitelným nedostatkem podmínky řízení, který v každé fázi řízení vede $\mathrm{k}$ jeho zastavení. ${ }^{23}$ Řízení pak bude zastaveno opravdu v jakékoli fázi ř́zení, a to bez ohledu na délku řízení. Ústavní soud např. odmítl ústavní stížnost stěžovatelky, kyperské společnosti, která namítala porušení svého ústavního práva na př́istup $\mathrm{k}$ soudu tím, že předmětné řízení bylo pro nedostatek pravomoci zastaveno až po 8 letech řízení. Argumentovala přitom rozhodnutím Ústavního soudu ve věci I. ÚS 487/04, ve kterém tento označil zastavení řizení pro neexistenci pravomoci obecných soudů po 13 letech probíhajícího sporu za neústavní. ${ }^{24}$ Ústavní soud se nicméně s danou argumentací neztotožnil, když poukázal na to, že na rozdíl od stávající věci nešlo v jeho předcházejícím rozhodnutí o spor s mezinárodním prvkem, nýbrž o práva zaměstnance vyplývající ze služebního poměru, což právo na př́istup $\mathrm{k}$ soudu daleko více zvýrazňovalo. ${ }^{25}$

Současně ovšem platí, že v případech, kdy pravomoc českých soudů k projednání a rozhodnutí věci nebyla dána $\mathrm{v}$ době podání návrhu, ale $\mathrm{v}$ době, kdy soud o tomto návrhu rozhodoval, již dána byla, není důvod zastavit řízení pro nedostatek pravomoci

19 HRÁDEK, J. Komentář k § 87. In: LAVICKÝ, P. Občanský soudní rád: praktický komentár̆. Praha: Wolters Kluwer ČR, 2016. In: ASPI [online]. [cit. 2021-04-19].

20 Usnesení Nejvyšš́iho soudu ze dne 30. 11. 2020, sp. zn. 25 Cdo 2669/2020.

21 PŘIDAL, O. Komentár k § 87. In: SVOBODA, K. - SMOLÍK, P. - LEVÝ, J. a kol. Občanský soudní řád. 2. vyd. Praha: C. H. Beck, 2017, s. 378.

22 Usnesení Nejvyššího soudu ze dne 24. 7. 2017, sp. zn. 32 Cdo 547/2017.

23 Usnesení Nejvyššího soudu ze dne 24. 7. 2017, sp. zn. 32 Cdo 547/2017.

24 Nález Ústavního soudu ze dne 28. 11. 2007, sp. zn. I. ÚS 487/04.

25 Usnesení Ústavního soudu ze dne 27. 2. 2018, sp. zn. II. ÚS 3381/17. 
podle stavu ke dni zahájení ŕízení. ${ }^{26}$ Ustanovení $§ 6$ ZMPS totiž váže pravomoc českých soudů na to, že je dána jejich příslušnost - není v něm ovšem na rozdíl od § 11 OSŘ obsažena zásada perpetuatio fori, podle které by pro závěr o nedostatku pravomoci byly až do skončení ř́zení rozhodné okolnosti, které tu jsou v době jeho zahájení. ${ }^{27} \mathrm{Na}$ druhou stranu však není podstatné, že podmínka pravomoci byla někdy během řízení splněna. Není-li dána pravomoc českých soudů k projednání a rozhodnutí věci v době podání návrhu na zahájení řizení a ani v době, kdy soud o tomto návrhu rozhodoval, pak skutečnost, že tato podmínka řízení byla nebo mohla být splněna někdy v průběhu takto vymezeného úseku rrízení, nemá vliv na správnost závěru o nedostatku pravomoci soudu. ${ }^{28}$

\section{URČOVÁNÍ ROZHODNÉHO PRÁVA PODLE ZMPS}

$\mathrm{Na}$ rozdíl od úpravy pravomoci českých soudů nenalezneme v ZMPS obecnou kolizní normu, ale pouze zvláštní kolizní normy pro jednotlivé právní poměry v části čtvrté. Pouze pro případy, kdy rozhodné právo není možné pro daný právní poměr určit na základě jiných ustanovení ZMPS, je rozhodným právem podle $\S 24$ odst. 2 ZMPS právo, které je s ním v nejužším vztahu. Toto ustanovení nicméně nemůžeme chápat jako obecnou kolizní normu, ale pouze jako normu pro subsidiární určení rozhodného práva.

\subsection{KOLIZNÍ ÚPRAVA V § 101 ZMPS}

Kolizní normu pro mimosmluvní závazkové poměry nalezneme ve zvláštní části ZMPS, Hlavě XI (Závazková práva), Díle 9 (Některé mimosmluvní závazkové poměry). Tento díl je tvořen jediným paragrafem, $\S 101$, který obsahuje kolizní normu pro mimosmluvní závazkové poměry vznikající z narušení soukromí a osobnostních práv včetně pomluvy. Důvodem pro omezený rozsah je skutečnost, že většina mimosmluvních závazkových poměrů spadá pod působnost Nařízení Řím II - prostor pro aplikaci autonomních kolizních norem tedy zůstává jen pro oblasti vyloučené z jeho věcné působnosti, přičemž mezi tyto patří právě i mimosmluvní závazky z narušení soukromí a osobnostních práv včetně pomluvy. ${ }^{29}$

Mimosmluvní závazkové poměry vznikající z narušení soukromí a osobnostních práv včetně pomluvy se podle $\S 101$ ZMPS řídí právem státu, ve kterém k narušení došlo. Hraničním určovatelem je tedy místo narušení soukromí a osobnostních práv z uvedeného opět není bez dalšího zcela jasné, zda je míněno lex loci delicti commissi

26 Usnesení Nejvyššího soudu ze dne 28. 1. 2016, sp. zn. 29 Cdo 5258/2014, a zde citovaná judikatura Nejvyššího soudu.

27 Usnesení Nejvyššího soudu ze dne 29. 4. 2010, sp. zn. 29 Cdo 1578/2008. I když se výklad poskytnutý Nejvyšším soudem v této věci týkal § 37 zákona č. 97/1963 Sb., o mezinárodním právu soukromém a procesním, tedy právním předchůdci ZMPS, vzhledem k obdobnému znění § 6 ZMPS se tyto závěry uplatní i v režimu ZMPS.

28 Usnesení Nejvyššího soudu ze dne 20. 6. 2012, sp. zn. 29 Cdo 20/2012.

29 Viz čl. 1 odst. 2 písm. g) Nařízení Rím II. 
či lex loci damni infecti. Že je narušením míněno protiprávní jednání, je ovšem naštěstí patrné z dalšího textu tohoto ustanovení, které dává postižené osobě mj. právo volby práva státu, ve kterém se dostavil výsledek narušujícího jednání. Pokud je tedy lex loci damni infecti v zákoně uvedeno jako alternativa, je zřejmé, že základním pravidlem musí být lex loci delicti commissi. Český zákonodárce se tedy přiklonil k tradičnějšímu hraničnímu určovateli lex loci delicti commissi na rozdíl od zákonodárce evropského, který jako základní hraniční určovatel v Nařízení Řím II zvolil lex loci damni infecti. ${ }^{30}$

Kromě hraničního určovatele místa narušení však český zákonodárce zároveň do § 101 ZMPS zakotvil i flexibilní prvek spočívající v možnosti postižené osoby rozhodné právo zvolit. ${ }^{31}$ Tato volba nicméně není neomezená - postižený má možnost zvolit pouze již zmíněné právo místa újmy nebo místa svého obvyklého pobytu či sídla, popř. místa obvyklého pobytu či sídla původce narušení. U lex loci damni infecti je navíc zákonem stanoveno omezení, podle kterého může poškozený zvolit právo země, ve které se dostavil výsledek narušujícího jednání pouze $\mathrm{v}$ př́ípadě, že původce narušení mohl předvídat, že se právě v daném státě výsledek jeho narušujícího jednání dostaví.

Pokud zůstaneme u místa narušujícího jednání, vyvstávají nám dvě otázky, na které nedává zákon zcela jednoznačnou odpověd' - zaprvé jde o otázku výkladu místa narušujícího jednání a zadruhé o otázku rozhodného práva v př́ípadě, kdy k narušení dojde na území více států. U slovně vyřčené pomluvy je určení místa jednání poměrně snadné - jde o místo jejího vyřčení. Komplikovanější situace bude nicméně v př́ípadech publikace předmětné informace $\mathrm{v}$ tištěných médiích nebo na internetu. Valdhans se $\mathrm{v}$ tomto ohledu kloní k názoru, že lze vycházet z judikatury SDEU ve věci Shevill a ve věci eDate Advertising, ${ }^{32}$ ve které bylo pro tyto př́ípady za místo protiprávního jednání soudem označeno místo obvyklého bydliště či sídla vydavatele. ${ }^{33}$ Jedná se sice o judikaturu k unijnímu předpisu, a to navíc mezinárodního práva procesního, ${ }^{34}$ a uvedené závěry by tak neměly být převzaty bez dalšího, $v$ tomto konkrétním prrípadě je ovšem podle mého názoru použít lze. Ostatně české soudy na tuto judikaturu odkazují i v př́padech čistě vnitrostátních, při výkladu českého procesního práva, ${ }^{35}$ nebylo by proto překvapivé, kdyby tak učinily i v př́ípadě výkladu ustanovení § 101 ZMPS.

$\mathrm{K}$ otázce určení rozhodného práva $\mathrm{v}$ př́ípadě, že $\mathrm{k}$ narušení došlo na území více států, nám zákon, ale ani judikatura (a to ani unijní) ${ }^{36}$ neposkytují zatím žádnou odpověd’. Nabízí se minimálně dvě řešení. Prvním je tzv. mozaikový princip, podle kterého se narušení v každém státě posuzuje podle práva daného státu. Jde o princip používaný sice zpravidla v prípadě hraničního určovatele lex loci damni infecti, jeho použití si lze

30 Viz čl. 4 odst. 1 a Odrážky (15) a (16) Preambule Nařízení Ŕím II.

31 VALDHANS, J. Komentár k § 101. In: PAUKNEROVÁ, M. - ROZEHNALOVÁ N. - ZAVADILOVÁ, M. Zákon o mezinárodním právu soukromém: komentár. Praha: Wolters Kluwer ČR, 2013, s. 652.

32 Rozsudek ze dne 7. března 1995, Shevill a další v. Presse Alliance (C-68/93, EU:C:1995:61); a rozsudek ze dne 25. ř́jna 2011, eDate Advertising a další (C-509/09 a C-161/10, EU:C:2011:685).

33 VALDHANS, Komentár $k$ § 101, s. 653.

34 Konkrétně čl. 5 odst. 3 Bruselské úmluvy ze dne 27. září 1968 o př́slušnosti a výkonu rozhodnutí v občanských a obchodních věcech a čl. 5 odst. 3 Nařízení Brusel I (čl. 7 odst. 2 Nařízení Brusel I bis).

35 Konkrétně $§ 87$ písm. b) OŠ̌ - viz již výše citované usnesení Nejvyššího soudu ze dne 30. 11. 2020, sp. zn. 25 Cdo 2669/2020.

36 Výše citovaný rozsudek SDEU ve věci Shevill, ve kterém došlo k zakotvení tzv. mozaikového principu, se zabýval primárně otázkou mezinárodní př̌́slušnosti v př́ípadě vzniku škody na území několika státù. 
ovšem představit i v př́ípadě lex loci delicti commissi. Jeho zřejmou nevýhodou je nicméně aplikace práva hned několika právních řádů najednou, což není př́iliš praktické. Jako praktičtější alternativa se jeví ponechání této otázky na úvaze soudu, aby určil stát, kde došlo k narušení v nejpodstatnější míře. ${ }^{37}$

K možnosti postižené osoby zvolit si rozhodné právo lze učinit dvě poznámky. První je konstatování, že se jedná o volbu omezenou - jak bylo uvedeno výše, postižená osoba má právo zvolit pouze právo místa svého obvyklého pobytu, obvyklého pobytu narušitele a právo místa, kde došlo k narušujícímu jednání. Pro srovnání lze uvést, že Nařízení Řím II v čl. 14 žádné obdobné omezení nestanoví, a volba práva tedy není $\mathrm{v}$ tomto ohledu nařízením omezena. Volba práva podle nařízení však není jednostranným právním jednáním poškozeného, ale musí být založena na dohodě stran, která byla uzavřena poté, co došlo ke skutečnosti, jež vedla ke vzniku škody. ${ }^{38}$ Možnosti poškozeného jsou tedy podle českého práva fakticky širší, nebot' dosažení dohody stran ohledně rozhodného práva poté, co došlo ke škodné události, budou poměrně vzácné. Každá ze stran bude totiž přirozeně usilovat o to, aby bylo za rozhodné zvoleno právo takového státu, které bude lépe chránit její pozici. Druhou poznámkou k volbě práva podle § 101 ZMPS je otázka jejího okamžiku. V komentářové literatuře najdeme jak názor, že volbu je možné učinit v návrhu na zahájení ř́izení či v průběhu řízení, ${ }^{39}$ tak restriktivnější výklad, podle kterého by volba měla být učiněna nejpozději při prvním úkonu ve věci samé. ${ }^{40}$ Osobně bych se klonila $\mathrm{k}$ druhému výkladu, a to i s ohledem na právní jistotu stran a soudu, podle kterého práva bude daná věc posuzována.

\subsection{URČENÍ ROZHODNÉHO PRÁVA NA ZÁKLADĚ ÚNIKOVÉ DOLOŽKY}

V ZMPS na rozdíl od úpravy obsažené v Nařízení Řím II není výslovně zakotvena výjimka společného bydliště stran, a tedy zakotvení hraničního určovatele lex domicili communis. ${ }^{41}$ Tento alternativní hraniční určovatel umožnuje v př́padech, kdy škůdce a poškozený pocházejí ze stejného státu (mají stejnou státní př́slušnost, obvyklý pobyt ve stejném státě aj.), nahradit lex loci delicti tímto „společným“ právem a patří mezi nejčastěji používané výjimky ze základního hraničního určovatele. ${ }^{42}$

$\mathrm{V}$ př́ípadech, kdy $\mathrm{v}$ rámci použití ZMPS budou mít strany společné bydlišstě, vyvstává nejprve otázka, jestli je mezinárodní prvek v daném př́padě dostatečně významný (a nikoliv zanedbatelný), a zda tedy vůbec přichází aplikace kolizních norem v úvahu. ${ }^{43}$

37 BŘÍZA, P. Komentář k § 101. In: BŘÍZA, P. - BŘICHÁČEK, T. a kol. Zákon o mezinárodním právu soukromém: komentář. Praha: C. H. Beck, 2014, s. 574.

38 Dohodu o volbě práva lze uzavř́t i před tím, než dojde ke skutečnosti, jež vede ke vzniku škody, ale jen v př́padě, že všichni účastníci jednají v rámci své podnikatelské činnosti. Viz čl. 14 odst. 1 písm. b) Nařízení Rím II.

39 VALDHANS, Komentáŕ k § 101, s. 653.

40 BŘíZA, c. d., s. 574.

41 Viz čl. 4 odst. 2 Nařízení Řím II.

42 SYMEONIDES, S. Codifying choice of law around the world: an international comparative analysis. Oxford: Oxford University Press, 2014, s. 58.

$43 \mathrm{~V}$ české nauce mezinárodního práva panuje shoda na tom, že mezinárodní prvek musí být pro daný poměr dostatečně relevantní, nikoli zjevně zanedbatelný. Viz PAUKNEROVÁ, M. Evropské mezinárodni právo soukromé. 2. vyd. Praha: C. H. Beck, 2013, s. 3; nebo KUČERA, Z. - PAUKNEROVÁ, M. - RÚŽIČKA, K. a kol. Mezinárodní právo soukromé. 8. vyd. Plzeň - Brno: Aleš Čeněk - Doplněk, 2015, s. 24; 
Pokud ano, bylo by možné právo společného bydliště stran aplikovat na základě volby postižené osoby podle $\S 101$ ZMPS, popř. v krajním př́padě pomocí všeobecné únikové doložky podle $\S 24$ odst. 1 ZMPS.

Všeobecná úniková doložka umožnuje ve zcela výjimečných případech nepoužít právního řádu určeného na základě ustanovení ZMPS v případech, kdy by se to jevilo jako nepřiměřené a odporující rozumnému a spravedlivému uspořádání vztahu účastníkủ. Zohledněny by měly být všechny okolnosti dané věci a důvodná očekávání účastníků ohledně použití jiného právního řádu. Cílem všeobecné únikové doložky je dosažení kolizní spravedlnosti. ${ }^{44}$ Únikové doložky by však mělo být užito jen velmi restriktivně a každé její užití by mělo být řádně odůvodněno. Mezi okolnosti, které by soudce měl před její aplikací zvažovat, patří kromě již uvedených relevantních okolností dané věci právě i otázka kolizní spravedlnosti a př̌iměřenosti, ale také ochrany práv třetích osob. ${ }^{45}$

\subsection{ROZSAH A LIMITY ROZHODNÉHO PRÁVA}

Ohledně rozsahu rozhodného práva určeného na základě $§ 101$ ZMPS nenalezneme $\mathrm{v}$ zákoně žádný př́kladmý výčet, lze však souhlasit $\mathrm{s}$ názorem, že lze analogicky použít čl. 15 Nařízení Rím II ${ }^{46}$ a to s výjimkou pravidel o promlčení, nebot' ZMPS obsahuje zvláštní kolizní normu pro otázku promlčení v $\S 46 .{ }^{47}$

Rozhodné právo určené na základě kolizní normy v $\$ 101$ ZMPS (či v krajním případě na základě $§ 24$ odst. 1 či 2) má ovšem své limity v podobě imperativních ustanovení a výhrady veřejného pořádku.

Imperativní ustanovení neboli nutně použitelné normy jsou v ZMPS upraveny mj. $\mathrm{v} \S 3$, podle kterého nejsou rozhodným právem dotčeny nutně použitelné normy českého práva. Tyto normy nejsou v zákoně nijak blíže vymezeny, jedná se ovšem o takové normy, které nemohou být $\mathrm{v}$ mezích svého předmětu úpravy zásadně zaměněny či nahrazeny cizím právem. ${ }^{48} \mathrm{~V}$ tomto ohledu pak představují pro aplikaci rozhodného práva významné omezení. Zpravidla se jedná o veřejnoprávní normy správního a finančního

a BĚLOHLÁVEK, A. J. Římská úmluva a Nařizení Řím I: komentář. I. díl. Praha: C. H. Beck, 2009, s. 150 .

44 ROZEHNALOVÁ, N. Instituty českého mezinárodního práva soukromého. Praha: Wolters Kluwer ČR, 2016, s. 44.

45 PAUKNEROVÁ, Prostor pro uváženi v českém mezinárodním právu soukromém ..., s. 19.

46 Čl. 15 Nařízení Řím II:

„Rozhodným právem pro mimosmluvní závazkové vztahy podle tohoto nařizení se rídí zejména

a) základ a rozsah odpovédnosti, včetně určeni osob, které mohou nést odpovědnost za své jednáni;

b) důvody pro vyloučeni odpovědnosti, omezeni odpovědnosti a rozdělení odpovědnosti;

c) určení vzniku škody, jeji povahy a posouzeni nebo nárokovaného odškodnění;

d) opatření, která mǔze soud príijmout v rozsahu své pravomoci podle procesního práva, aby zabránil vzniku nebo trvání škody na zdravi nebo na majetku anebo aby zajistil náhradu této škody;

e) otázka, může-li dojit k prevodu práva na uplatněni nároku na náhradu škody nebo odškodnění, včetně dèdèním;

f) určení osob oprávněných k náhradě škody utrpěné jimi osobně;

g) odpovédnost za jednání jiné osoby;

h) zpưsob zániku závazku a pravidla o promlčeni a prekluzi, včetně pravidel o počátku, prererušení a stavení bèhu promlčecí doby nebo prekluzivnich lhìt. "

47 BŘÍZA, c. d., s. 575.

48 KUČERA - PAUKNEROVÁ - RŮŽIČKA, $c$. $d$., s. 231. 
práva - typickým příkladem jsou např. omezení dovozu a vývozu či embarga. Pokud totiž není možné dané zboží do př́islušné země dovážet, je irelevantní, že se smlouva ohledně tohoto zboží řídí jiným právem. Nejedná se ovšem pouze o předpisy regulující zahraniční obchod - z oblastí potenciálně relevantních pro mimosmluvní závazkové poměry lze např. jmenovat předpisy týkající se ochrany životního prostředí či bezpečnosti provozu. ${ }^{49}$

Aplikace imperativních norem práva fóra, která je zakotvena v § 3 ZMPS, je tradiční, všeobecně akceptovanou zásadou, takže v tomto ohledu není úprava ZMPS nijak zvlášt' specifická - zásadní je naopak otázka aplikace zahraničních imperativních norem, a to jak těch, které jsou součástí legis causae, tak norem práva třetího státu. ${ }^{50}$

Aplikace zahraničních imperativních norem, které jsou součástí práva rozhodného pro daný právní poměr, je upravena v $§ 23$ ZMPS. ${ }^{51}$ Toto ustanovení upravuje otázku zjišt'ování a používání zahraničního práva a stanoví mj. i to, že se zahraničního legis causae má použít tak, jak se ho používá na území, na němž toto právo platí. Ustanovení zahraničního práva má být také užito bez ohledu na jeho systematické zařazení nebo veřejnoprávní povahu. Do uvedeného pak nepochybně patří i imperativní normy legis causae. Pro pořádek je však potřeba uvést, že toto neplatí v př́ípadě, že by normy zahraničního práva byly v rozporu s nutně použitelnými ustanoveními práva českého - právo fóra má tedy fakticky $v$ tomto ohledu přednost.

Pravidla použití zahraničních imperativních norem práva třetího státu nalezneme v § 25 ZMPS. Použití těchto norem je ovšem možné pouze na návrh účastníka a návrh není pro soud závazný. Ustanovení § 25 ZMPS jasně stanoví, že jich je možné použít v př́ípadě, že práva a povinnosti, o které jde, mají k takovému třetímu státu dostatečně významný vztah a jejich užití je spravedlivé vzhledem k povaze a účelu těchto ustanovení a důsledkům jejich (ne)užití pro strany. Obsah a platnost imperativních norem třetího státu musí prokázat účastník, který se jejich uplatnění dovolává.

V ZMPS ovšem nenalezneme explicitní povinnost soudu přihlížet při posuzování jednání pachatele deliktu k pravidlům bezpečnosti a chování platným v místě jednání, která je zakotvena např. v čl. 17 Nařízení Řím II a v čl. 7 Haagské úmluvy o právu použitelném pro dopravní nehody. Jako pravidla bezpečnosti a chování označujeme pravidla platná v místě protiprávního jednání, která by měla být zohledněna při posuzování jednání pachatele deliktu $\mathrm{v}$ př́padech, kdy rozhodným právem je právo jiného státu. ${ }^{52}$ Koncepce těchto pravidel je založena na tom, že pachatel deliktu měl jednat v souladu s pravidly vydanými státem, v němž jednal, a to bez ohledu na právo rozhodné pro následné soukromoprávní důsledky jeho chování. ${ }^{53}$

49 PAUKNEROVÁ, M. Komentáŕ k § 25. In: PAUKNEROVÁ, M. - ROZEHNALOVÁ, N. - ZAVADILOVÁ, M. Zákon o mezinárodním právu soukromém: komentár. Praha: Wolters Kluwer ČR, 2013, s. 183.

50 PAUKNEROVÁ, M. Imperativní normy a mezinárodní právo soukromé - klasické téma v současnosti. Právník. 2021, roč. 160, č. 1, s. 5.

51 REMSOVÁ, K. Uplatnění koncepce nutně použitelných ustanovení dle zákona o mezinárodním právu soukromém. In: ROZEHNALOVÁ, N. - DRLIČKOVÁ, K. - VALDHANS, J. Dny práva 2015. Část IV., Kodifikace obecné části kolizního práva - cesta či omyl? Brno: Masarykova univerzita, 2016, s. 194.

52 SYMEONIDES, c. d., s. 88.

53 VALDHANS, J. Mezinárodně-soukromoprávní tvář profesora Týče, neboli od lex loci delicti commissi k lex loci damni infecti. In: KYSELOVSKÁ, T. - SEHNÁLEK, D. - ROZEHNALOVÁ, N. (eds.). In 
Objevují se sice názory, že při hodnocení naplnění předpokladů vzniku deliktní odpovědnosti je tato pravidla nutné brát $\mathrm{v}$ potaz, ${ }^{54}$ faktem ale zůstává, že zákon výslovnou úpravu této otázky neobsahuje. Vzhledem $\mathrm{k}$ tomu, že pravidla bezpečnosti a chování jsou zpravidla součástí imperativních norem, přichází jejich aplikace v úvahu právě pouze $\mathrm{v}$ rámci jejich aplikace podle výše uvedených ustanovení. $\mathrm{V}$ př́ípadě, kdy rozhodné právo nebude právem místa protiprávního jednánín ${ }^{55}$ a místo jednání se nebude nacházet na území ČR, jedinou možností bude jejich aplikace prostřednictvím $§ 25$ ZMPS. Jak ovšem bylo naznačeno výše, jeho použití podléhá poměrně přísným podmínkám a s formulací čl. 17 Nařízení Řím II, které přímo stanoví povinnost k pravidlům bezpečnosti platným v místě jednání při posuzování chování škůdce přihlížet, jej nelze srovnávat.

Výhrada veřejného pořádku je obsažena v § 4 ZMPS, který stanoví, že ustanovení zahraničního právního řádu, jehož se má použít podle ustanovení ZMPS, nelze použít, jestliže by se účinky tohoto použití zjevně příčily veřejnému pořádku. Jedná se o standardní ustanovení, jehož cílem je prevence důsledků použití zahraničního práva, které by v tuzemském prostředí byly považované za nesnesitelné a neudržitelné. ${ }^{56}$

\section{UZNÁNÍ A VÝKON CIZÍCH ROZHODNUTÍ PODLE ZMPS}

Pro úpravu uznání a výkonu cizích rozhodnutí musíme opět do obecné části ZMPS - stejně jako u úpravy pravomoci neobsahuje ZMPS ve své zvláštní části speciální úpravu pro mimosmluvní závazkové poměry.

Uplatní se tedy obecná úprava obsažená v §§ 14-16 ZMPS..$^{57}$ Podle $§ 14$ mají v ČR zahraniční rozhodnutí účinnost, jestliže nabyla podle potvrzení př́slušného cizího orgánu právní moci a byla-li uznána českými orgány veřejné moci. $V$ prŕpadě rozhodnutí v majetkových věcech se uznání nevyslovuje zvláštním výrokem, ale je uznáno tím, že k němu český orgán veřejné moci přihlédne, jako by šlo o rozhodnutí české. Na základě cizího rozhodnutí, které splňuje podmínky uznání, je možné nařídit výkon tohoto rozhodnutí rozhodnutím českého soudu, které je třeba odůvodnit.

V zákoně jsou ovšem zároveň stanoveny i překážky uznání pravomocných cizích rozhodnutí $-\mathrm{v} \S 15$ ZMPS je stanoven taxativní výčet důvodů, pro které tato rozhodnutí není možné uznat, a tedy ani vykonat. Při jejich posouzení je však vždy nutné brát $\mathrm{v}$ potaz to, že rozhodnutí nelze přezkoumávat ve věci samé. ${ }^{58}$

Většinu těchto důvodů pak lze označit jako procesní překážky uznání a výkonu cizího rozhodnutí, které nemají př́ímou souvislost s hmotněprávním posouzením či dru-

varietate concordia: soubor vědeckých statí k poctě prof. Vladimíra Týče. Brno: Masarykova univerzita, 2019 , s. 473.

54 VALDHANS, Komentár k $\$ 101$, s. 655.

55 Např. na základě volby práva postižené osoby či na základě aplikace všeobecné únikové doložky.

56 Viz Důvodová zpráva k zákonu č. 91/2012 Sb., o mezinárodním právu soukromém, č. 91/2012 Dz.

57 Ustanovení §§ 17-19 ZMPS upravují postup v ř́zeních o uznání a výkonu cizích rozhodnutí, v nichž se postupuje podle př́mo použitelných předpisů EU nebo mezinárodní smlouvy, které vyžadují prohlášení vykonatelnosti (exequatur).

58 KUČERA - PAUKNEROVÁ - RŮŽIČKA, c. d., s. 377. 
hem uplatňovaného nároku, a nejsou tak specifické pouze pro oblast mimosmluvních závazkových poměrů. Uznat a vykonat tak nelze např. rozhodnutí, u kterého existuje překážka litispendence či věci rozhodnuté nebo u kterého není zaručena vzájemnost.

Vzhledem $\mathrm{k}$ tomu, že rozhodnutí ve věcech mimosmluvních závazkových poměrů ani nepatří do oblastí, které náleží do výlučné pravomoci českých soudů, není relevantní ani tento důvod pro odepření uznání a výkonu. ${ }^{59}$ Naopak nedostatek mezinárodní soudní př́islušnosti orgánů cizího státu takovým relevantním důvodem být může. Cizí rozhodnutí totiž není možné uznat $\mathrm{v}$ př́ípadech, jestliže by řízení nemohlo být orgány cizího státu vedeno, kdyby se ustanovení o př́slušnosti českých soudů použilo na posouzení pravomoci cizího orgánu. Pokud tomu tak není, nemá podle představ českého zákonodárce cizí orgán $\mathrm{k}$ věci dostatečně silný vztah, a rozhodnutí tak nelze uznat. ${ }^{60} \mathrm{Zde}$ je ovšem nutné doplnit, že do ,ustanovení o př́slušnosti českých soudü “nejsou zahrnuty jen předpisy vnitrostátní (ZMPS a potažmo OSŘ). Podle judikatury Nejvyššího soudu totiž mezi tato pravidla patř́ i jurisdikční pravidla zakotvená $\mathrm{v}$ unijních předpisech, jež jsou nedílnou součástí českého práva, jakož i jurisdikční pravidla zakotvená v mezinárodních smlouvách, kterými je ČR vázána. ${ }^{61} \mathrm{~V}$ daném prrípadě se jednalo o uznání a výkon rozhodnutí arizonského soudu o náhradu škody z titulu tvrzeného poškození žalobce (slovenského občana) webovými stránkami v českém jazyce, které vytvořil žalovaný (český občan) ve spolupráci s arizonskou společností. Soud prvního stupně návrh na nařízení exekuce podle tohoto rozsudku zamítl mj. právě s odůvodněním, že podle procesních předpisů České republiky (a v tehdejší době převažující judikatury k místu vzniku škody podle $\S 87$ písm. b) OSŘ citované výše) by arizonský soud př́slušný k projednání této žaloby nebyl. Nejvyšší soud ovšem rozhodl, že pro posouzení toho, zda by mohl být $\mathrm{k}$ projednání žaloby mezinárodně př́islušný arizonský soud, je použitelný i čl. 5 odst. 3 Nařízení Brusel I. Toto rozhodnutí bylo vydáno sice ve vztahu k úpravě obsažené v zákoně č. 97/1963 Sb., o mezinárodním právu soukromém a procesním, tedy právnímu předchůdci ZMPS, nicméně tento konkrétní závěr je nepochybně aplikovatelný i v rámci ZMPS. Tento důvod pro odepření uznání a výkonu nicméně není možné použít $\mathrm{v}$ případě, kdy se účastník řízení, proti němuž cizí rozhodnutí směřuje, pravomoci cizího orgánu dobrovolně podrobil.

Dalším, pro př́pady mimosmluvních závazkových poměrů potenciálně relevantním důvodem pro odepření uznání a výkonu cizích rozhodnutí, je zjevný rozpor s veřejným pořádkem. Je pravdou, že i výhrada veřejného pořádku bude častěji použita $\mathrm{v}$ souvislosti s porušením procesních práv v řízení ve státě původu nežli z důvodů hmotněpráv-

59 Mezi př́ípady výlučné pravomoci patří v ZMPS ustanovení $\$ 39$ odst. 1 (prohlášení občana ČR za mrtvého či nezvěstného), § 60 odst. 3 (rozhodování o osvojení nezletilého dítěte, které je občanem ČR a má na území ČR obvyklý pobyt) a § 68 (rozhodování o věcných právech k nemovitým věcem na území ČR). Výlučná pravomoc českých soudů pak nemusí být dána jen na základě ustanovení ZMPS, ale i mezinárodních smluv a unijního práva. Obdobně i PFEIFFER, M. - ZAVADILOVÁ, M. Recognition and enforcement of judgments in commercial matters rendered by courts of non-eu countries in the Czech Republic. Acta Universitatis Carolinae Iuridica. 2020, Vol. LXVI, č. 4, s. 164.

60 JIRMANOVÁ, M. Komentář k § 15. In: PAUKNEROVÁ, M. - ROZEHNALOVÁ, N. - ZAVADILOVÁ, M. Zákon o mezinárodním právu soukromém: komentár. Praha: Wolters Kluwer ČR, 2013, s. 110.

61 Usnesení Nejvyššího soudu ze dne 22. 8. 2014, sp. zn. 30 Cdo 3157/2013. 
ních. ${ }^{62}$ Výjimku nicméně v tomto ohledu představuje uznání a výkon rozsudku, kterým byly přiznány tzv. punitive damages neboli sankční, nekompenzační náhrada škody, kterou známe zejména z amerického právního prostředí. V české, ale i kontinentální doktríně panuje $\mathrm{v}$ tomto ohledu shoda, že punitive damages jsou zpravidla $\mathrm{v}$ rozporu s veřejným pořádkem, a to kvůli zakotvení sankčního prvku do téměř výhradně kompenzační funkce náhrady škody. ${ }^{63}$ Podle judikatury Nejvyššího soudu však není možné výkon rozhodnutí, ve kterém byly přiznány punitive damages, z důvodu rozporu $\mathrm{s}$ veřejným pořádkem bez dalšího odepřít. Tento názor přitom Nejvyšší soud vyslovil ve stejném rozhodnutí, které bylo citováno výše. Arizonský soud totiž v tomto sporu přiznal žalobci náhradu škody ve výši 100 000,- USD a žalovaný v řízení před českými soudy namítal, že se nepochybně jedná o nekompenzační náhradu škody, nebot’ žalobci zřejmě žádná škoda ve státě Arizona nevznikla, a proto by měl být její výkon pro rozpor s českým veřejným pořádkem odmítnut. Podle názoru Nejvyššího soudu je nicméně uplatnění výhrady rozporu s veřejným pořádkem možné pouze tehdy, pokud je výše sankční náhrady újmy zjevně nepřiměřená újmě, již má odškodnit. ${ }^{64}$ Rozpor s veřejným pořádkem není totiž dán jen proto, že české právo nezná institut cizího práva, na kterém je cizí rozhodnutí založeno. Naopak jej lze dovodit pouze v př́ípadě, že by účinky rozhodnutí byly v rozporu s některou ze základních zásad, na nichž je český právní rád založen. U sankční náhrady újmy tomu tak bude právě v prŕípadě zjevné nepřiměřenosti přiznané částky ke způsobené újmě, která bude $\mathrm{v}$ takovém př́ípadě $\mathrm{v}$ rozporu $\mathrm{s}$ čl. 11 odst. 1 Listiny základních práv a svobod, nebot' bude představovat nepřiměřený zásah do práva vlastnit majetek.

\section{ZÁVĚRY}

Jak bylo uvedeno výše, je prostor pro aplikaci českého autonomního mezinárodního práva soukromého $\mathrm{v}$ oblasti mimosmluvních závazkových poměrů $\mathrm{v}$ současné době stále poměrně široký a znalost této úpravy je tedy nezbytnou součástí řešení každého takového poměru.

V návaznosti na výše uvedenou analýzu lze konstatovat, že česká úprava je v tomto ohledu úpravou kvalitní, odpovídající moderním trendům mezinárodního práva soukromého. Jedná se o úpravu předvídatelnou, ale i dostatečně flexibilní, kdy lze ocenit zejména úpravu práva volby rozhodného práva pro postiženou osobu a zakotvení všeobecné únikové doložky. Ve vztahu k mimosmluvním závazkovým poměrům lze vytknout pouze absenci zakotvení povinnosti přihlížet $\mathrm{k}$ pravidlům bezpečnosti a chování

62 PFEIFFER - ZAVADILOVÁ, c. d., s. 167.

63 ŽIVĚLOVÁ, A. Umožňuje nový občanský zákoník přiznat v řízení o náhradě nemajetkové újmy punitive damages? Bulletin advokacie. 2016, č. 4, s. 24-30; BĚLOHLÁVEK, A. J. Účast na řízeních o hromadných žalobách v zahraničí a uznání a výkon rozsudků v těchto věcech v jiných zemích. Právní rozhledy. 2016, č. 13-14, s. 467-474; či VANLEENHOVE, C. A normative framework for the enforcement of U.S. punitive damages in the European Union: transforming the traditional no pasaran. Vermont Law Review. 2016, Vol. 41, No. 2, s. 347-404.

64 Usnesení Nejvyššího soudu ze dne 22. 8. 2014, sp. zn. 30 Cdo 3157/2013. 
platným v místě protiprávního jednání, nicméně lze vyjádřit naději, že soudy budou $\mathrm{k}$ těmto pravidlům $\mathrm{v}$ rámci posouzení protiprávnosti daného deliktního jednání přihlížet i bez výslovného zakotvení této povinnosti v zákoně.

Mgr. Kateřina Holečková

Právnická fakulta Univerzity Karlovy

Kacaholec@seznam.cz 